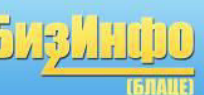

Часопис из области економије менаџмента и информатике Година 2017, волумен 8, број 1, стр. 55-68

\section{Bi'-1/Difo}

Journal of Economics, Management and Informatics

Year 2017, Volume 8, Number 1, pp. 55-68

Стручни рад/ Professional paper

УДК/UDC: 005.336.5:005.57

808.5

DOI: $10.5937 /$ bizinfo1701055N

\title{
ACQUISITION OF BASIC PUBLIC SPEAKING SKILLS
}

\section{СТИЦАҢЕ ОСНОВНИХ ВЕШТИНА ГОВОРНИШТВА}

\author{
Nataša Novaković ${ }^{1}$ \\ Business School of Applied Studies, Blace, Serbia \\ Boris Teodosijević \\ Successful Club, Subotica, Serbia
}

\begin{abstract}
With this texst we show that the acquisition of oratorical skills means not only mastering certain techniques of oratory, or public speaking, but that this is largely primarily related with a kind of mental preparation of speakers themselves, or in which way will future speakers access oratory as an art form or a skill, how will they experience oratory in their own understanding of this beautiful but demanding craft, craft that rewards us with different and great achievements in communication with our environment. Of course, provided that they are well prepared to master the art of public speaking. This preparation involves understanding and exploring the experiences of other well-known speakers, so that we get to know their own way to a magnificent oratory. Than it is necessary to set a clear goal to ourselves of what we want to achieve by studying these skills. Of course, our personal opinion, feeling and consciousness of public speaking must be positive and always strive for success. And above all, it is important to take every opportunity to exercise our public appearances and public speaking because exercise makes perfect.
\end{abstract}

Key words: basic public speaking skills, experience of others, goal, exercise

Резиме: Овим радом показујемо да стицање говорничких вештина не подразумева само савладавање одређених техника ораторства, или

${ }^{1}$ novakovicnatasa@yahoo.com 
јавног наступа, него да је то увелико скопчано првенствено са својеврсном менталном припремом самих говорника, односно са тиме на који ће начин будући говорници да приступе говорништву као вештини, како ће дожсивљавати говорништво у сопственом разумевану овог лепог али и захтевног заната, заната који нас награђује различитим и великим успесима у комуникацији са намом околином. Наравно, под условом да се добро припремимо за овладавање вештином говорништва и јавног наступа. Та припрема подразумева сагледавање и истраживање искуства других познатих говорника, како би смо спознали њихов пут до врхунског говорништва. Затим је потребно себи поставити јасан ичиь тога шта желимо да постигнемо изучавањем ове вештине. Дакако, наш лични став, осећање и свест о говорништву морају бити позитивни и увек тежсити ка успеху. Те изнад свега, важно је да искориштавамо сваку прилику за вежбање нашег јавног наступа и говорништва, јер вежбом стварамо савршенство.

Кьучне речи: основне вештине говорништва, искуства других, изиљ, вежба

\section{BASIC OF PUBLIC SPEAKING SKILLS}

Learning communication is essential for all areas of life. It's an effective and sometimes the only way to resolve numerous problems and improve interpersonal interaction. Communication is a constant phenomenon that occurs on all levels of life and in all forms of business. It improves our own selfimage. We always communicate whether we are aware of that or not, whether we want to or not. Our every move, motion, reaction, every behavior that we're not aware of, makes a certain type of interaction, communicates something about us and our intentions (Mihajlov, 2012. p. 9).

When we thing about public speaking and start studying of rhetoric, very soon we come to the conclusion that public speaking is guided by certain rules and laws, and that gives us specific recommendations that we should follow in order to master that skill. By doing so, we will not see public speaking in a context of historical ancient oratory or flamboyant skill, which sometimes has a goal only to impress the listener, but to devote ourselves to public speaking as a practical and pragmatic skill, that will allow us to achieve specific objective, business or personal nature, through interaction with our interlocutors and audience.

Surely, we can look at public speaking in the light of business communication, which is the key in achieving every business success. By looking at the communication of one business entity with other organisations, a market and individuals, we can perceive the significance of business communication - public relations and marketing and communication 
channels, through which the business entity establishes a connection with the outside word, which is important for survival on the market, and above all for a successful business (Vrgović, Hinić, Matijević and Barać, 2010). In other terms, we need the knowledge from the area of business communication, a narrow area of rhetoric, for a successful business of any kind.

When thingking about business communication, we inevitably have to consider today's technological development and whith that, the development of new means of communication. Digital media, the internet and social networks, gratly change the the current way of communication and how we address our target audience. A new communication paradigm is a logical consequence of the revolution brough by social networks. Only a decade ago it took several hours to transfer certain information, and the production chain involved a larger number of people. Thanks to social media, today we only need minutes (Novaković, Mićunović and Stefanović, 2015.)

What does the acquisition of basic oratory skills imply and do these basic skills include learning how to write and make our own speaches? Actually, the answer is negative, because at this time we will not be dealing with speaches, their preparation, with ways of their presentation and similar, but we will exclusively focus on ourselves as speakers. We will deal with how to prepare ourselves, better yet our personality, attitude and character, in order to become good speakers.

How can we acquire basic oratory skills? What can we do in order to become good speakers? How ca we get ready for speaking? Those are some of the fundamental questions that need to be answered by everyone who begins to study oratory. Sometimes we get the answers through practice, many decades of business experience and inevitable communication that derives from it, but sometimes that is not enough, because if business experience were enough, then we would witness that all the slightly older generations of business people are also excellent speakers, which of course is not the case. That experience, nonetheless can be of great help in mastering the art of oratory.

Otherwise, if selfeducation through experience is a harder way and a way tha doesn't yield good results, or good results require decades of observation and contemplation about our own experience, in order to extract practical knowledge, what is then the better and faster way to achieve the desired goals?

In your search for great mentors and quality knowledge, use all means at your disposal. Read books on this topic from many authors, attend various courses, seminars, lecture, search the internet for different texts, or better yet, video 
seminars and observe everything critically with active thinking. It is very important, that you observe the material or your work with methors in such way where you actively think about if that specific information or knowledge that is given to you, is applicable in your circumstances of future public appearance. This is very important for one simple reason - public appearance, or oratory, is a segment of communication and interpersonal interaction, and that interaction greatly depends on a large number of external factors and circumstance, which don't necessarily conside with the circumstances in which your mentor gained his knowledge.

To concretize this question. The way we address others, largely depends on which culture, tradition and heritage we belong to, and certain rules that apply to the culture of our teacher, may not apply to our and at the same time they can't be applied in our particular circumstances of public appearance. Often happens, when learning skills such as speaking, sales, business negotiation and others, we 'take for granted' what the authority says and by blindly applying those rules we do more harm than good. It is important to know the culture and customs of people that you're learning from, the culture and customs of your own surroundings and of course the culture and custome of the audience that you are addressing, if it's not from your national or geographical background.

Therefore, it's best that we directly look at a few general ways in acquiring basic rhetorical skills which are not dependent on external factor, but are entirely related to yourself and your experience of oratory and public speaking itself. Let's look at the techniques that will help you form your personal attitude and views towards speaking as a skill, thus helping you to form your mind and structure it so it allows you to easily master the rhetoric skill and make public speaking become a completely ordinary and normal activity, where you're getting along well and feel great.

\section{FIND MOTIVATION IN THE EXPERIENCE OF OTHERS}

Marina Markovic in her book 'Business communication' says that the skill of public speaking is studied in three basic ways, of which to us, at this moment, the most interesting is the third, the empirical process, which represents communication with different structures and groups, identifying the needs of clients and at the moment is particularly significant is accepting the positive experience of successful business partners and associates, or other speakers. (Marković, 2000. p. 25)

For starters, over the years we surely though and wondered how did others acquire the knowledge and the ability to bee good speakers so that we perceive their performace as excellent, no matter how we look at them. We 
might have done some research and watched a few YouTube videos, in order to see other speaker and see how do they do it. Then we might have asked ourselves what their personal experience in public speaking are, and their experience in learning the skill of public speaking and public appearance. What did they do in order to become such good speakers, that we nowadays watch online or on television? What does their experience tell us?

So, the first and foremost thing that we ask is have those excellent speakers, that we see today, became famous and popular speakers at once, or were they even born that way? Just because they are excellent speakers and they speak in front of a huge audience and they are wanted around the world, definitely doesn't mean that they became excellent ad hoc or that they were born this way. In other words, they all eventually became excellent. They all improved their skill of public speaking and appearance, so today they could be such great speakers.

Another question arises, which is 'What did they exactly do?'. So we should look back at their journey and observe what these people specifically did in order to become what they are today. We can probably find a lot of videos on the internet, on YouTube channels of top international speakers, let's say American speakers, in English, where they speak about how they alone started with their oratory skill, how they were bad speaker, how they had stage fright and were afraid, how they barely made it out in front of the audience, how it was all a disaster, and how they went through the process of learning, improvement and so on.

Inevitably, another question arises. What do you think, are good speakers born, or they become good speakers, or it's something in between? The majority of people say that "People become good speakers in time', so they become, learn to be good speakers. This is the answer of the absolute majority, which is mostly likely your answer as well. I will say something entirely opposite. Good speakers are born!

We might be concerned about this answer, but there's no need to worry, all will be explained. When we say that good speaker are born, that doesn't mean 'Alright, since I'm not born as a good speaker, I will never be a good speaker!'. On the contrary. I want to say something entirely diferent, and we will reach that point after I ask a few more questions. Do we know one group of people that has no problem with public appearance? One group that surrounds us and is not afraid of, or ashamed for public speaking. This group are children.

Why they don't have a problem with public appearance? And when saying little childer, I literarly mean little childer, pre-teenagers and even younger. 
They don't have a proble with public appearance because of one simple reason, because problem with public appearance is really a problem of fear of public appearance, and the fear of public appearance is an acquired fear. Here I must set a clear distance that when saying that small children don't have that fear, then we are talking about the majority. We are not talking about cases where children experienced some kind of trauma in their early childhood, or their development is compromised or have some phycological of physical disabilities, then they clearly have a problem with public appearance. So we will ignore those extremen cases and will talk about the majority of health and hormal children.

The following fact is also interesting. Those who are in psychology or pedagogy, know the following. The only two fears, inherited in the human species, so the only two fears we inherit by birth are the fear of sudden intense noise and the fear of losing the ground under our feet. The second one is not the fear of hights but the fear of losing the ground under our feet. These are the only two fears that every person is born with. There are no fear of hights, fear of spiders or public speaking, nor any other type of fear but only the fear of sudde intense noise and the fear of losing the ground under our feet.

So what do we draw as a conclusion? Children while they're growing up, are feel and relaxed 'speakers'. Free public speakers, no matter how rough that may sound. Children do this freely because they have no fear, no backlash from it. Until one moment, and that moment is called 'socialization' or upbringing. That's the moment when we, as parents, tell our kids 'OK please stop dancing, playing, jumping, reciting, we have guests. Go to your room and play.' or 'Ugh son you're annoying, leave me alone with your poems. Honey don't always dance around us. You will break something.' And so three times and children tell themselves 'Wait a minute. This what I'm doing is wrong, because my parent's are telling me - don't!'. Once, twice, trice don't! When they are told 'Don't', children slowly and gradualy withdraw into themselves. Of course this can be a slow or a sudden process, depending on the tone and what way of communication parents use in forbidding their childred to express their natural urge for public appearance. Some kids withdraw less and slower, some withdraw more and faster, and performs its public appearance in its own room, and not in from of people thus gradually forming the fear of public appearance.

There is another group of people in our surroundings, that generaly has no fear of public appearance. These are the Roma people. Roma people usually don't have the fear of public appearance, because in their culture, which I agree with, it is custom to stimulate childred for performance, so to speak. They stimulate their children to dance, sing, jump, talk to everybody, do 
whatever, thus they don't have problem with public appearance. They are musicians, dancers, singers, it all comes naturaly for them. In fact, how does it sound when I say it all comes naturaly 'for them'. In fact that comes naturaly to every human being on the planet, up until the moment when it's stopped, in early childhood.

In line with what we talked about earlier, it's obvious that there are differences in cultures and perceptions of social acceptions of public appearance and expression of ones own wishes, opinion, ideas and similar. In western culture that freedom is a little restrained, under the platitude of not endangering other's freedon, while in many eastern cultures it's still custom that people express more freely and directly. The question is, where are we? In some customs of communication we belong more to the east, because we behave more close with our interlocutors, we exchange more physical contact, while in terms of public speaking and oratory we belong more to West, because that form of expression to often presents as a problem.

Out of this entire stoje, the most important conclusion is that we should perform, because we are born to. We are all born go be good public 'performers', good public speakers, good in what ever you think of. We are born to be free and then in one moment for stopped being. Now comes a moment when we all have to re-learn, to re-motivate ourselves to what we once were, to what we once had. So, this moment I'm telling you a beautiful thing, and that is that you will in fact have to learn the thing you already have by nature, what you already know, so you only need to set yourselves fee and to become what you once were. This doesn't mean that you have to become kids, but in that context, it's okay if you are a little childish, play, because that will greatly help you master these skills that we are talking about.

So, what are the experience of others? When we search for the experience of others and learn their life stories, we will conclude that they've all be through the same thing. Maybe they were like children, but don't know and are not aware of it, also good public speakers, and then they lost it, and after that with hard work, regained it. Of course, if we are interest in further studying the paths of different speakers, in order to get more familiar under what kind of circumstances they acquired their skills, and what have the used in order to overcome their own fears, doubts or confusion, I commend that you do that. Soon you will learn that the path of acquiring their oratory skills for many of them was quite similar.

What is important is that you can also regain it, and I will tell you another small secre. In fact, you don have to work too hard in order to allegedly acquire some new knowledge and skills and so on. No, you just have to open up yourself to what you naturaly are. Just allow your nature to feely express 
itself and to come out of you. That's one way in preparing yourself to be a good public speaker.

\section{ALWAYS KEEP YOUR GOAL IN FRONT OF YOU}

Another way that you can prepare yourself to be a good speaking is as follows. Always keep your goal in front of you. Now this might sound a bit philosophical, because what does it meak to have your goal in front of you? Of course we all sometimes tell ourself something like 'I want to win', or 'One day, I want to be seen by a stadium of 50 thousand people while I speak.'. That's not disputed, but that's not the goal at this moment. Your goal at this moment is to be a good speaker. That is not measure by the number of people in the audience, or the number of speacher you will give, but with how the audience perceives you, are you interested for them and are they gladly listening to you (Карнеги, 2006).

What's the easiest way to keep our goal of being a good speaker in front of us? Simply by saying "I am a good speaker'. Now we will move over onto another subject that we will only mention in passing, the subject of NLP (neuro-liguistic programming). In this context we don't tell ourselves "I will be a good peaker in the future.'. What does that mean? That future may not come to pass, because that is something that is always in the distance of the undefined future. Instead we say 'I will be a good public speaker'. Furthermore, even if it's incorrect for our language, we can also way "I am a good speaker in six months.". I am - in six months. So we are, as if that already happened, but we need a little time, so those six months. And even better, we won't say six undefined months, but we will say on such and such date, on such and such year, I am a great speaker. Have a clear and fixed goal in frond of you.

So, when we think about what we will accomplish, we don't thing about something far, that is over there in the distance, that we will, mabe, eventually accomplish. We look at it as if it's already in front of us. Just like looking at ourselves in the mirror and in that mirror we already see a successful person, a perso that has great appearance, a good entertainer, speaker, politician that speaks well, a company manager that can win over any business partner, or anything else that we can imagine, that is as a result directly connected to your public speaking ability.

In essence, we have at our disposal five simple ways on how to always keep our goal in front of us, such as: constantly reminding ourselves about the goal, setting out specific and not general goals, putting a deadline for achieving the goal, bulding up responsibility for success or failure, determining a reward for accomplishing the goal (Inc, 2013). 


\section{PROGRAMMING OUR MIND FOR SUCCESS}

Third way - program your mind for success. What does this mean and is this another philosophi? We will discover that this is one really concrete way of behavior and thinking, that inevitably provides good results.

Program your own mind that you are a winner. How does that work and why? The subconsciousness accepts thought that are repeated frequently. When it accepts them, that changes our way of thinking, our habits and actions. This leads to contacts with new people, situations and circumstances. (Success Sonsciousness, 2001.)

This moment I will reveal one uncomfortable truth, which we usually hear a bit differently. We usually hear 'It's important to participate.' No, ladies and gentlemen, it's not important to participate, it's important to win! Everybody can participate. This doesn't mean that you have to walk over others around you in order to win, but when it comes to speaking, somebody has to get hurt in order for you to get your chance. This inevitably reminds me of a proverb from the American culture. When someone steps out to do some kind of performance, give a speech, sing, dance, then the others tell him 'Break a leg'. This should mean 'Good luck' but to us it doesn't sound like it. So it's not necessary for someone to break a leg in order for you to be successful in your public appearance. All that is necessary is you to tell yourself that you will surely succeed, and of course you need to support that with adequate preparation, learning and exercise.

As an illustration, picture two athletes, identical twins, that are physically completely identical and that they are both runners. They trained an equal amount of time, under the same conditions, with the same equipment, same coach, under the same circumstances, everything is completely the same. The day of the race. Of course, both of them want to win the race. But one of them says "I will try to win this race' and the other one says 'I already won this race. All I need is for the referee to hit the start.' What are the odds in the majority of cases, who will really win that race? I believe you said it yourself 'Well the other one, the one that said he already won the race.'

That is not false selfconfidence, meaning that the other athlete didn't work on himself and he only says "I will win the race' and that is enough. In that case, it's no different if we tell ourselves 'I will win the lotery', just because we bought a ticket. Of course we can't look at it that way, because both athletes worked, tried and prepared equaly with an additional difference of absolute selfconfidence and conviction in their own success. Looking at the same 
thing from a public speaking point of view, it's necessary that we're absolutely confident and sure that we already are good speakers. All that we need, along with the positive attitude, is to inform ourselves more and to master certain public speaking techniques, in order to have a solid foundation for a good public appearance. The fact is that a positive attitude makes us better speakers faster, helps us to win, rather than a negative attitude which reflects in the words "Well okay, I will try and see what happens."

Let's see what really happens to those athletes, and also to us in the process of learning public speaking, in the case of doubt for a positive outcome, or when we perform with such positive attitude, without any doubt about the outcome. We will ignore philosophical stands, energy, spirituality and similar, and focus only on the physical aspect of such thinking. The athlete that said 'I will try' has prepared himself, there's tension before the rase, maybe some jitters or stomach cramps, because in this moment he must do something for what he was preparing all those years and what is really important to him, his body secretes a mixture of adrenaline and cortisol, heatrate increases, blood pressure rises, his muscles are pretty constricted, in general, the level of stress rises. All this, signals his body to get ready for a 'dangerous situation', and in situations like this, our body can have three natural reactions: fight, flight or petrify. Was the previous situation familiar and similar to when you had to stand in front of the crown and give a speech? Which one of these three reactions to stress and danger is the best or at least good in case of public speaking? Neither. They are all wrong and not one of them will help you become a good speaker.

Whils at the other athlete that says 'I already won' that same difference in the attitude results in different chemistry in his system. A little less adrenaline, perhaps more serotonin and melatonin, hormones that make you happy and relax you. That different chemistly makes you relaxed. It's enough for the muscles of the second athlete to be a bit more relaxed so he could stretch an inch more and to win the race even if it's by that little. When it comes to speaking, it's enough that the chemistry as a result of us saying "I already won, I'm already a good speaker, I will only rehearse a little more', relaxes us a bit, slows our heart rate and breathing, lowers the blood pressure and makes the entire process of learning easier, thus making us more relaxed in concrete situations when we step out in front of the audience to speak. The mere difference in our attitude can make us winners. Relax and get to work.

On the other hand, we shouldn't allow ourselves to fall into a trap where we tell ourselfves that positive thingking is enough and that all will play out well, and that we will overcome all obstacles in life with positive thinking. That's not the case and we clearly pointed this out in our previous example with the athletes that they both trained equaly for the race. Therefore, since we want to 
be good speakers, we will aslo have to devote ourselves in studying of the oratory skill and techniques of public appearance in order to ensure our success. The good thing is that a positive attitude and properly programmed mind, be of great help in the learning process itself and of course in the actual practice of speaking.

\section{USE EVERY OPPORTUNITY FOR PRACTICE}

The last thing, very important in acquiring basic public appearance skills, is that we have to use every opportunity to rehearse our public appearance. Rehearsing means practice which usually refers to putting the theoretical knowledge to practical use, through constatnt cycle of conceptualizing the meaning of what can be learned from experience. Rehearsal is a process through which the adopted theory, lesson or skill is practices, embodied or realized. Practice can refer to the act of recruitment, application, rehearsal, understanding and testing of ideas (Boundless, 2016).

Now we are reaching the following questions or problems. How and when can we have the chance to rehesrse? Where will you give speaches simply for the sake of rehearsing? Where will we give lectures for the sake of preparing those same lectures? You might be in a situation that you have an upcoming presentation in front of your board of directors, or you will do a sales presentation, political speech, an expect lecture. So it's close, a real speech and public appearance, and not some chance for rehearsal, but a real deal that you must do. In that case when and how do we get the opportunity for any kind of rehearsal? Also, after that one, we don't know when will the next one be, nor we don't know what the circumstances will be like. Will it be a less important appearance, though which we can rehearse the learned techniques, or will the next case be of great importance, where we cannot play and study our rhetoric?

Public appearance is not just giving speeches in fron of large masses. Or as the definition says: Public speaking is every addressing of one individual towards a group or individual listener, whether live or through electronic means of communications, with a sole purpose of achieving a certain goal, or presenting a certain image of ourselves, through different techniques of influence, informing and entertaining. Although Encyclopædia Britannica has slightly different definition of public speaking, or rhetoric, where it says: "Oratory, elaboration and practice of convincing public speaking' wheras 'Rhetoric, the classical theoretical basics for the art of rhetoric, which is the art of efficient use of words" (Encyclopædia Britannica, 1995).

With that regard we can rehearse public appearance in every moment of our lives, even at home. We can rehearse with our family member, colleagues at 
work, friends, and acquaintances that we meet along the way, and even with strangers on the street. All that we have to do is to be aware of our performance, to keep track of what is going on during, and to have a clear goal about what we want to achieve with that performance.

Since it's not entirely clear how can we practice every day and in almost every situation, here's another practical exercise that we can do, as soon as we leave our house.

For example, we can go to the store where we usually go often, maybe every single or every other day. Especially if that's a store that is sometimes crowded and there's a queue at the cash register, even better. If we can, go to the store at the end of one shift or near the end of business hours. The reason why we sould go at the end of a shift, is because for the sake of this exercise, that makes the circumstances a bit difficult, but it also increases the chance for success. It's a fact that the cachiers are already tired, they've been ther all day, dealth with hundreds and thousands of customers, they've had enough and would rather go home. They are also a little bit nervous.

What do we need to do? Unlike every other time, let's not simply pass by like it's an everyday routine we don't think about, with less or without any interaction with people. We might or might not say hello and even if we do, it's just a formality without any honesty or any true emotions. Instead, from the moment we enter the store or pass the cashier, if we pass the cashier on our way in, we will establish first eye contact. Even then we will give a slight smile. Then, when we come to the cash register, waiting in queue, smile sincerely and sincerely ask her how is she doing. Or we can say 'Hello neighbor, we meet once again. Here I am again.' or something similar. When we are done shopping, we'll say 'Thank you very much. I'll see you again tomorrow.' with another sincere smile and eye contact.

Do your performance towards that person thinking about the effect that you want to achieve. Of course, just to be clear, the desired effect is not that when you go to the store the next day, you skip the queue or something similar. The cashier won't do that and that's not the point. Instead you will notice the following. When you to that and a similar performance once, then again the folliwng day, the third time when you get to the same register, the cashier will recognize you from all the other customers and will especially smile for you and speak with you in a different tone, a better more pleasant tone. In time, this way you can make friends with someone. Or at least to become buddies.

We can do the same thing with somebody on the streen, at work with our coworkers, with our boss, subordinates, superiors, family members, it doesn't 
matter. And all that, can be a pubic appearance. So in every omment we can do a public appearance, even though it's not a direct lecture or a speech in a business environment, it's not directly what are we learning here. Everything can turn into a public appearance under just one condition. To think and enter these conversatins fully aware, just like you start your speech. To consciously think about the rules fo that public appearance that you're doing in that moment, even if it last only 15 seconds, it doesn't matter. Everything that we read so far can be applied right now. For starters, go outside as soon as you finish with this article and do the previous exercise, if that is possible.

Atlernatively, this exercise can also be done if you go to a corner shop where you go often and where you will go again and do the exact same thing, or you meet with people you usually hang out with and you will surely see them again and do the same exercise, just using different sentences which you will prepare ahead. It's only important that you do this fully aware and thinking about the effect that you want to achieve. All that remains is to follow up on the effect of the exercise after the second or third time.

\section{CONCLUSION}

Rhetoric is not just about preparing a concrete speech, for a concrete situation and specifi audience, but in the beginning it mainly involves preparing ourselves as future speakers.

In order to illustrate and better understand, rhetoric can be viewed as any other craft. In order to become a good craftsman, we need to fulfill a few important requirements. Firstly we need to have an appropriate outfit and protective gear (programming our minds for success), get ourselves familiar with the tools that we will use (rhetoric techniques), get ourselves familiar with the work material (diversity of audience), to observe how a master craftsman does it and to follow his advices (stimulus from other's experience), to know up ahead what will our first craft work look like, latter on how will our own master crafts look like (having the goal in front of us), to use every break with the master and every piece of waste material to craft our own test items (using every opportunity for practice).

Only when we pass the apprentice period, which we cannot skip, because it's the foundation of our future work, we can move on to further studies of all techniques and secrets of public appearance, which we make us a master of oratory skill. 


\section{РЕФЕРЕНЦЕ}

1. Карнеги, Д. 2006. Како брзо и лако савладати говорничку вештину. Београд: Политика, Народна књига.

2. Marković, M. 2000. Poslovna komunikacija. Oblikovanje govora u odnosima sa javnošću. Beograd: Clio.

3. Encyclopedia Britannica 1995. Oratory-rhetoric. [online] Available through: <http://www.britannica.com/art/oratory-rhetoric> [Accessed 10 April 2015.].

4. Entrepreneur, 1994. The Extraordinary Power of Visualizing Success. [online] Available through: $<$ https://www.entrepreneur.com/article/242373> [Accessed 12 April 2015.].

5. Success Consciousness, 2001. Creative Visualization - From Imagination to Reality. [online] Available through: <http://www.successconsciousness.com/index_000008.htm> [Accessed 12 April 2015.].

6. Boundless Communications, 1996. The Importance of Rehearsing. [online] Available through: <https://www.boundless.com/communications/textbooks/boundlesscommunications-textbook/delivering-the-speech-12/rehearsing-thespeech-67/the-importance-of-rehearsing-265-7315/> [Accessed 15 May 2015.].

7. Vrgović, P., Hinić, D., Matijević, N., Barać, M. 2010. Poslovno i organizaciono komuniciranje. Bar: Fakultet za poslovni menadžment.

8. Inc, 1996. 5 Ways to Keep Your Eye On the Goal. [online] Available through: <http://www.inc.com/eric-v-holtzclaw/5-ways-to-keep-youreye-on-the-goal.html> [Приступ 23.05.2013.].

9. Новаковић, Н., Мићуновић, Г., Стефановић, Г. 2015. ИТ будућност која је већ почела. Бизинфо (Блаще), 6(1), стр. 11-33.

10. Mihajlov, S. 2012. Poslovne komunikacije. Blace: Visoka poslovna škola strukovnih studija.

Рад је примљен: 21.05.2016.

Враћен на корекцију: 09.06.2016.

Прихваћен за објављивање: 10.02.2017.

Received: 21 May, 2016

Corrections suggested: 9 June, 2016

Accepted: 10 February, 2016 